\title{
Competition Periods of Crabgrass with Rice and Soybean CROPS $^{1}$
}

\author{
Períodos de Competição de Milhã com as Culturas do Arroz Irrigado e da Soja \\ AGOSTINETTO, D. ${ }^{2}$, FONTANA, L.C. ${ }^{2}$, VARGAS, L. ${ }^{3}$, PERBONI, L.T. ${ }^{2}$, POLIDORO, E. ${ }^{2}$, and \\ SILVA, B.M. ${ }^{2}$
}

\begin{abstract}
Determining the periods of weed competition with crops helps the producer to choose the most appropriate time to use weed control practices. This strategy allows for the reduction of the number of herbicide applications, reducing costs and the environmental impact of pesticides. The objectives were to determine the period before the interference (PBI) of crabgrass (Digitaria ciliaris) competing with flooded rice, the critical period of interference prevention (CPIP) of crabgrass with soybean and the effects of competition on the grains yield and their components. Experiments were conducted with the coexistence of BRS Querência rice cultivar with crabgrass, for periods of $0,7,14,21,28,35$, and 110 days after emergency (DAE) and Fundacep 53RR soybean cultivar, whose periods of coexistence and control of crabgrass were $0,7,14,21,28,35$, and 156 DAE. Rice can grow with crabgrass infestation until $18 \mathrm{DAE}$, while soybean should remain free from the presence of crabgrass in the period between 23 and 50 DAE. The grain yield and its components, in the crops studied, are affected when grown with crabgrass.
\end{abstract}

Keywords: Digitaria ciliaris, Oryza sativa, Glycine max, interference

RESUMO - A determinação dos periodos de competição das plantas daninhas com as culturas auxilia o produtor na escolha do momento mais adequado para utilizar medidas de manejo. Essa estratégia possibilita reduzir o número de aplicações de herbicidas, com consequente redução de custo e menor impacto dos agrotóxicos ao ambiente. Assim, os objetivos deste trabalho foram determinar o periodo anterior à interferência (PAI) de milhã (Digitaria ciliaris) na cultura do arroz irrigado, o periodo crítico de prevenção à interferência (PCPI) de milhã na cultura da soja e os efeitos da competição na produtividade de grãos e seus componentes. Para isso, foram conduzidos experimentos de convivência de arroz irrigado, cultivar BRS Querência, com milhã, por periodos iniciais crescentes de 0, 7, 14, 21, 28, 35 e 110 dias após a emergência (DAE), e de soja, cultivar Fundacep 53RR, cujos periodos de convivência e controle de milhã foram de 0, 7, 14, 21, 28, 35 e 156 DAE. A cultura do arroz irrigado pode conviver com milhã até $18 D A E$, enquanto a soja deve permanecer livre da presença de milhã no periodo entre 23 e 50 DAE. A produtividade de grãos e seus componentes, nas culturas estudadas, são alterados pela convivência com milhã.

Palavras-chave: Digitaria ciliaris, Oryza sativa, Glycine max, interferência.

\section{INTRODUCTION}

Weed competition results in decreasing crop yields, as reported in flooded rice (Balbinot Jr. et al., 2003; Agostinetto et al., 2007) and soybean (Steckel \& Sprague, 2004; Nepomuceno et al., 2007). These yield losses vary according to the population of weeds, area distribution, emergence flows, and the size of the individuals due to the time of emergence in relation to the crop.

To avoid that competition limit the productive potential of the crop, weed control

1 Recebido para publicação em 29.8.2013 e aprovado em 17.1.2014.

2 Universidade Federal de Pelotas, Pelotas-RS, Brasil, <dirceu.agostinetto@pq.cnpq.br>; ${ }^{3}$ Embrapa Trigo, BR 285 - Km 174 , Passo Fundo-RS, <leandro.vargas@embrapa.br>. 
is almost always necessary. Chemical control is used more, disregarding the crop ability in competing for the scarce resources of the environment. Chemical control occurs because herbicides application serves as an efficient control of weeds in great land extensions and in a short period of time.

The knowledge on the competition periods of weeds in crops helps in choosing the most appropriate time to use weed control practices (Radosevich et al., 2007). The possibility to wait for the time to carry out chemical control exists if the crop's cycle is already known, in which competition results in yield losses. This strategy allows for a lower number of herbicide applications, avoiding damage to the interference of weeds in the crop, with a consequent reduction of costs and less environmental impact of pesticides.

The degree of competition between weeds and crops can be altered due to the period in which the community is competing for a certain resource. It is known that the competition established in the early stages of the crop's cycle causes significant losses. However, at a certain period interference must be avoided, while at other periods weed control may not be necessary (Radosevich et al., 2007).

According to researches already performed, in the early development of the cycle, the culture and weeds can coexist for a determined period without damaging the yield. This stage is known as the period before the interference (PBI), when the environment is capable of providing the necessary resources for the community's growth. The second period, which is known as the total period of interference prevention (TPIP) is the one that the culture must grow free of the presence of weeds, for the yield crop to not be affected. From this period on, new weeds will not interfere so much to the point where the crop yield is reduced because the crop already presents a capability of suppressing competing plants. The third period, which is known as the critical period of interference prevention (CPIP) corresponds to the difference between PBI and TPIP, being the stage in which control practices should be effectively carried out in order to prevent irreversible losses in the crops yield (Radosevich et al., 2007).
There have been studies conducted under this methodology in many crops, such as soybean (Melo et al., 2001; Fleck et al., 2002; Nepomuceno et al., 2007), and rice (Agostinetto et al., 2007; Andres et al., 2008), which competed with different species of weeds. However, the competition periods of crabgrass (Digitaria ciliaris), with flooded rice and soybean, are still unknown. Therefore, the objectives of this research were to determine the period before the interference (PBI) of crabgrass competing with flooded rice, the critical period of interference prevention (CPIP) of crabgrass with soybean and the effects of competition on grains yield and their components.

\section{MATERIALS AND METHODS}

During growing season 2010/11, two trial design experiments with randomized blocks, with four replicates, were conducted. In the first experiment, with flooded rice, the experimental units had masonry boxes with a total area of $1 \mathrm{~m}^{2}(1 \times 1 \mathrm{~m})$ filled with $0.5 \mathrm{~m}^{3}$ of soil. The rice was cultivated using a conventional cultivation system, sowing cultivar BRS Querência with row spacing of $0.17 \mathrm{~m}$, and an established average population of 540 plant $\mathrm{m}^{-2}$. An average population of 504 plants $\mathrm{m}^{-2}$ of crabgrass was used collected on a floodplain agriculture area, in Santa Vitória do Palmar County.

The treatments were periods of coexistence of weed with crop flooded rice being kept in the company of crabgrass for periods of $0,7,14,21,28,35$, and 110 days after emergence (DAE). After this period, the control of crabgrass by manual uprooting of the plants was performed. The control periods of crabgrass were not included in this study because the entrance of water would stop the germination of crabgrass seeds. The available variables by the end of the crop cycle were plant height $(\mathrm{PH})$, number of grains per panicle (NGP), number of panicles (NP), one thousand grains' mass (TGM), apparent biological productivity (ABP), harvest index (HI), and grain yield ( $\left.\mathrm{kg} \mathrm{ha}^{1}\right)$.

The data were submitted to variance analyses and, being significant $(p<0.05)$, the averages were compared by Tukey's test $(\mathrm{p}<0.05)$. To determine PBI, based on grain 
yield, the data were submitted to regression analyses:

$$
\mathrm{y}=\mathrm{a} /\left(1+\left(\mathrm{x} / \mathrm{x}_{0}\right)^{\mathrm{b}}\right)
$$

where $\mathrm{y}=$ grain yield; $\mathrm{a}=$ estimated maximum yield on check treatment (without weeds); $\mathrm{x}=$ number of days post emergence; $x_{0}=$ number of days which occurred $50 \%$ of the maximum yield's reduction; and $\mathrm{b}=$ the curve's slope.

Crabgrass' period before interference (PBI) was estimated, deducting $3 \%$ of the flooded rice maximum yield, estimated by model corresponding to the cost of adopting a chemical control of weeds. For the calculations, the grain yield of $11.556 \mathrm{~kg} \mathrm{ha}^{-1}$ was considered, estimated by a mathematical model and a flooded rice $50 \mathrm{~kg}$ bag's price, last 8 years average (R\$25.46) (AGROLINK, 2011). In addition, the cost of cyhalofop herbicide at a dosage of $1.25 \mathrm{~L} \mathrm{ha}^{-1}\left(\mathrm{R} \$ 131.25 \mathrm{ha}^{-1}\right)$, aerial spraying $\left(\mathrm{R} \$ 30.00 \mathrm{ha}^{-1}\right)$ and adjuvant $\left(\mathrm{R} \$ 15.00\right.$ ha $^{1}$ ) was added. Based on these numbers, chemical control had a total cost of $\mathrm{R} \$ 176.25$, corresponding to $346 \mathrm{~kg}$ of rice $\mathrm{ha}^{-1}$.

The second experiment was conducted on a field, with soybean crop, and the experimental units were partials with a total area of $15.75 \mathrm{~m}^{2}$ $(5 \times 3.15 \mathrm{~m})$ and a useful area of $9 \mathrm{~m}^{2}$. Cultivar 'Fundacep 53RR' was tested, using a direct cultivation system, with row spacing of $0.45 \mathrm{~m}$ and density of 33 seeds $\mathrm{m}^{-2}$, which resulted in an average population of 24 plants $\mathrm{m}^{-2}$. Crabgrass was established in an average population of 112 plants $\mathrm{m}^{-2}$, originated from the seed bank present on the local soil.

Treatments were arranged on a two factor scheme, which corresponded to the times of coexistence and times of control of crabgrass. On coexisting times, the crop was kept in the presence of weeds for growing periods of: $0,7,14,21,28,35$, and $156 \mathrm{DAE}$, from which the weeds were controlled. On the controlling times, soybean was kept free from weeds during the same prior acknowledged periods. Meanwhile, crabgrass plants that emerged after those intervals were not further controlled. Control was done with the application of a glyphosate herbicide dose of $1.8 \mathrm{~L} \mathrm{ha}^{-1}$ (648 g e.a. ha ${ }^{1}$ ) at each time. Until the end of competition periods to $35 \mathrm{DAE}$, were evaluated shoot dry weight (SDW) in soybean and crabgrass plants and crop's height.
The grain yield resulted from harvested plants on an area of $5.4 \mathrm{~m}^{2}$, with grains' mass standardization to $13 \%$ humidity.

The data collected were subjected statistically and analyzed for normality and its homoscedasticity and, afterwards, submitted to variance analysis. Being significant $(p<0.05)$, the averages were compared by Tukey's test $(p<0.05)$. To determine the period of coexistence (PBI), a three parameters equation was used, as explained in the first experiment. Meanwhile, for the data that referred to the total period of interference prevention (TPIP), a four parameters equation was used:

$$
\mathrm{y}=\mathrm{y}_{0}+\mathrm{a} /\left(1+\left(\mathrm{x} / \mathrm{x}_{0}\right)^{\mathrm{b}}\right)
$$

where $\mathrm{y}_{0}=$ minimum yield obtained on infested treatment; $\mathrm{a}=$ the difference estimated by model between the maximum yield on check treatment (without weeds) and minimum yield on infested treatment. The other parameters were identical to the ones described for the equation that determines PBI determination.

The critical period of crabgrass interference was estimated deducting $3.17 \%$ of soybean's yield maximum estimated by model, in which its value corresponds to the cost of the chemical control of weeds. For the calculations, a yield of $2,175 \mathrm{~kg} \mathrm{ha}^{-1}$ was considered, estimated by a mathematical model, with the price of a $60 \mathrm{~kg}$ bag of soybean, average of the last ten years, $R \$ 35.65$ (AGROLINK, 2011). The other components were the cost of glyphosate herbicide, dose of $3 \mathrm{~L} \mathrm{ha}^{-1}\left(\mathrm{R} \$ 27.00 \mathrm{ha}^{-1}\right)$, and spraying by tractor $\left(\mathrm{R} \$ 13.60\right.$ ha $\left.^{1}\right)$. Based on these numbers, the chemical control cost was $R \$ 41.00$, corresponding to a $69 \mathrm{~kg}$ of soybeans ha-1.

\section{RESULTS AND DISCUSSION}

For the first experiment, variance analysis indicated significant differences among the periods of coexistence for the variables $\mathrm{PH}, \mathrm{NP}$, NGP, TGM, ABP, HI and grain yield, indicating alterations due to crabgrass competition. The $\mathrm{PH}$ of the flooded rice plant did not alter by coexisting with crabgrass until 14 DAE. However, coexistence through the crop's cycle end (110 DAE) resulted in 12\% reduction of rice $\mathrm{PH}$ compared to the average of the first three periods of coexistence (Table 1). 
Table 1 - Effect of the coexistence periods of crabgrass (Digitaria ciliaris) with flooded rice in the variables plant height, number of panicles, number of grains per panicle and thousand grains mass of culture

\begin{tabular}{|c|c|c|c|c|}
\hline $\begin{array}{c}\text { Periods } \\
\left(\mathrm{DAE}^{1 /}\right)\end{array}$ & Plant height $(\mathrm{cm})$ & $\mathrm{N}^{\mathrm{o}}$ panicles $\mathrm{m}^{-2}$ & $\mathrm{~N}^{\mathrm{o}}$ of grains per panicle & Thousand grain mass $(\mathrm{g})$ \\
\hline 0 & $76.9 \mathrm{a}^{2 /}$ & $827.8 \mathrm{a}$ & $78.5 \mathrm{a}$ & $23.8 \mathrm{a}$ \\
\hline 7 & $77.7 \mathrm{a}$ & $766.5 \mathrm{a}$ & $79.8 \mathrm{a}$ & $23.5 \mathrm{a}$ \\
\hline 14 & $77.4 \mathrm{a}$ & $758.9 \mathrm{ab}$ & $79.1 \mathrm{a}$ & $23.7 \mathrm{a}$ \\
\hline 21 & $73.1 \mathrm{ab}$ & $748.1 \mathrm{ab}$ & $74.4 \mathrm{a}$ & $23.4 \mathrm{a}$ \\
\hline 28 & $73.2 \mathrm{ab}$ & $633.4 \mathrm{bc}$ & $84.6 \mathrm{a}$ & $23.7 \mathrm{a}$ \\
\hline 35 & $72.6 \mathrm{ab}$ & $564.6 \mathrm{c}$ & $38.2 \mathrm{~b}$ & $22.2 \mathrm{~b}$ \\
\hline 110 & $68.3 \mathrm{~b}$ & $254.2 \mathrm{~d}$ & 13.7 & 3.4 \\
\hline $\mathrm{CV}(\%)$ & 3.5 & 8.7 & $\mathrm{a}$ & \\
\hline
\end{tabular}

$\underline{1}^{\prime}$ Days after emergence; $\stackrel{2 /}{ }$ Means followed by different letters, in the column, differ by Tukey’s test ( $\left.\leq 0.05\right)$.

NP was not modified itself until $21 \mathrm{DAE}$ (Table 1). However, the coexistence with crabgrass on 28 and $35 \mathrm{DAE}$ resulted in reductions on the NP produced by the crop, being the minor of them as a result of the coexistence with crabgrass during the entire flooded rice cycle. This highlights the fact that this component was the one that most influenced the crop's grain yield, as the variables NGP and TGM did not alter the periods of coexistence until $35 \mathrm{DAE}$, being the minors NGP and TGM were observed only when the crop coexisted along with crabgrass until 110 DAE.

ABP's evaluation, which serves as an indicator of the accumulated yield of dry weight from the aerial part of the plants during the development cycle, showed that it was not significantly altered until 21 DAE (Table 2). However, coexistence with crabgrass on 28 and $35 \mathrm{DAE}$ resulted in a reduction of this variable, being the minor ABP as a result of its coexistence with crabgrass during the entire crop cycle (110 DAE). A similar study showed that wheat crop responded differently, with minor ABP only when coexisting with ryegrass and turnip during the entire cycle (Agostinetto et al., 2008).

HI represents how much is converted from $\mathrm{ABP}$ to grain production. They were equivalent between the periods of coexistence until $35 \mathrm{DAE}$, differing only in their coexistence with crabgrass until 110 DAE, when the crop presented a minor $\mathrm{HI}$, confirming what was observed for wheat crop (Agostinetto et al., 2008).

The data that were obtained for the grain yield adjusted itself satisfactorily to the logistical equation, allowing for the calculation of the period in which crabgrass can infest flooded rice, without harming the crop yield (Figure 1). Considering the $3 \%$ value of a maximum estimated yield by equation (11.556 $\left.\mathrm{kg} \mathrm{ha}^{-1}\right)$, as being the cost for chemical control, it was determined that PBI for crabgrass occurred from emergence until $18 \mathrm{DAE}$ of the flooded rice crop.

Studies showed that PBI can have a lower duration than the one verified in the present

Table 2 - Effects of increasing periods of coexistence with the flooded rice with plants crabgrass (Digitaria ciliaris) in the variable biological productivity and harvest index the crop

\begin{tabular}{|c|c|c|}
\hline $\begin{array}{c}\text { Periods } \\
\left(\mathrm{DAE}^{1 /}\right)\end{array}$ & $\begin{array}{c}\text { Biological productivity } \\
\left(\mathrm{kg} \mathrm{ha}^{-1}\right)\end{array}$ & $\begin{array}{c}\text { Harvest index } \\
(\%)\end{array}$ \\
\hline 0 & $18856 \mathrm{a}^{2 /}$ & $0.52 \mathrm{a}$ \\
\hline 7 & $18165 \mathrm{ab}$ & $0.52 \mathrm{a}$ \\
\hline 14 & $17475 \mathrm{ab}$ & $0.55 \mathrm{a}$ \\
\hline 21 & $17531 \mathrm{ab}$ & $0.56 \mathrm{a}$ \\
\hline 28 & $15297 \mathrm{bc}$ & $0.58 \mathrm{a}$ \\
\hline 35 & $13727 \mathrm{c}$ & $0.57 \mathrm{a}$ \\
\hline 110 & $3058 \mathrm{~d}$ & $0.36 \mathrm{~b}$ \\
\hline $\mathrm{CV}(\%)$ & 8.3 & 7.6 \\
\hline
\end{tabular}

${ }^{1 /}$ Days after emergence; ${ }^{2 /}$ Means followed by different letters, in the column, differ by Tukey's test $(\mathrm{p} \leq 0.05)$. 


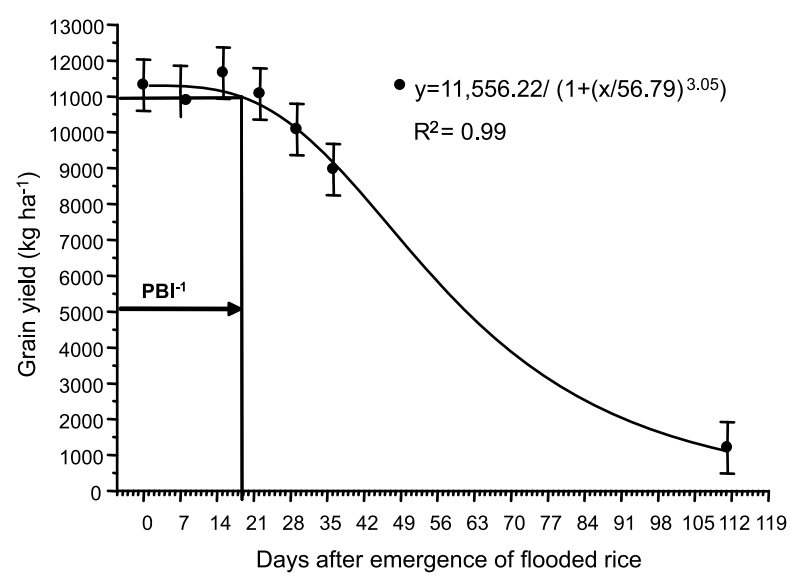

Figure 1 - Periods of coexistence of crabgrass (Digitaria ciliaris) in flooded rice based on grain yield. ${ }^{1}$ Period before interference. The vertical bars represent the confidence intervals $(\mathrm{p} \leq 0.05)$.

experiment, as 11 DAE (Andres et al., 2008). This variation is normal because it depends on the present species and population of weeds on an area, soil conditions, the climate at the location of where the experiment is being conducted, as well as its adopted handling techniques.

The negative effects of competition are irreversible, and there is no recovery on the development or the crop yield after the removal of the stress that is caused by weeds. Therefore, PBI becomes the period of higher importance for weeds, for it is from it that the yield is significantly affected, the end of PBI is the moment when the measures of weed control should be applied to prevent losses on the harvest's yield.

For soybean crop (second experiment), it was verified that until $35 \mathrm{DAE}$, the soybean $\mathrm{PH}$ did not differ significantly between the periods of control and coexistence (Figure 2), corroborating results from Nepomuceno et al. (2007), who did not observe any effect of competition on this crop's height. However, soybean's SDW differed between periods on $28 \mathrm{DAE}$, with less accumulation on plants that remained coexisting with crabgrass, pointing out a negative effect of competition.

The available variables by the end of the crop's cycle showed significant differences between periods of control and/or coexistence, demonstrating its being in competition with crabgrass for environment resources (Tables 3 and 4, Figure 3). In relation to the effects of competition on yield components, it was observed that NGP significantly differed only on 0 and $156 \mathrm{DAE}$, with bigger NGP offered by control on $156 \mathrm{DAE}$, and coexistence on $0 \mathrm{DAE}$, that is, in those treatments where there was no competition, once soybean developed itself on an area that was crabgrass free during the entire cycle (Table 3). The comparison between the periods of control showed that NGP was smaller when crabgrass was controlled only in emergence (0 DAE), given that the rest of the treatments with control did not differ from that one, except the last period, which demonstrated higher NGP. For periods of coexistence, it was verified that NGP was not altered until 156 DAE (Table 3).
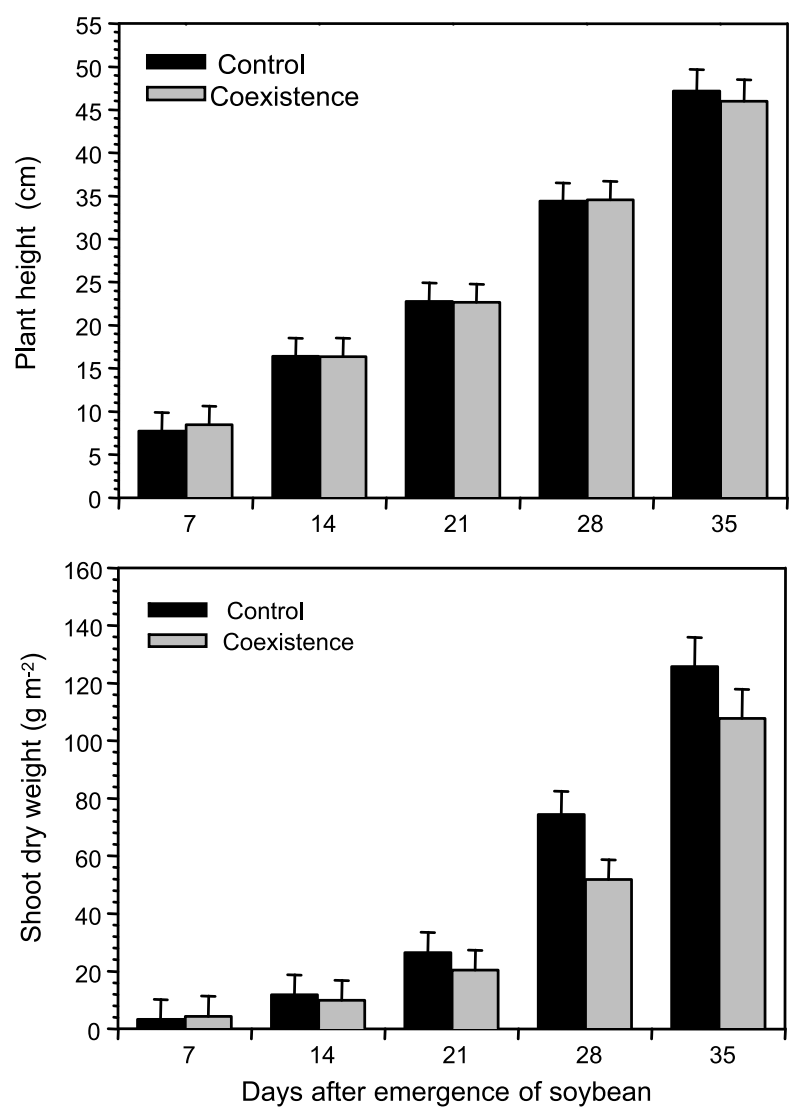

The vertical bars represent the confidence intervals $(\mathrm{p} \leq 0.05)$.

Figure 2 - Plant height and shoot dry weight of soybean in each control and coexistence periods crabgrass (Digitaria ciliaris). 
Table 3 - Effects of control and coexistence periods of crabgrass (Digitaria ciliaris) with soybean in variables number of grains per plant and thousand grain mass

\begin{tabular}{|c|c|c|c|c|}
\hline \multirow{2}{*}{$\begin{array}{l}\text { Periods } \\
\left(\mathrm{DAE}^{1 /}\right)\end{array}$} & \multicolumn{2}{|c|}{ Number of grains per plant } & \multicolumn{2}{|c|}{ Thousand grain mass $(\mathrm{g})$} \\
\hline & Control & Coexistence & Control & Coexistence \\
\hline 0 & $3 / * 38.4 \mathrm{~b}^{2 /}$ & $57.6 \mathrm{a}$ & ${ }^{\mathrm{ns}} 189.6^{\mathrm{ns}}$ & $205.4 \mathrm{a}$ \\
\hline 7 & ${ }^{\mathrm{ns}} 45.5 \mathrm{ab}$ & $60.3 \mathrm{a}$ & ${ }^{\mathrm{ns}} 180.4$ & $199.0 \mathrm{ab}$ \\
\hline 14 & ${ }^{\mathrm{ns}} 50.0 \mathrm{ab}$ & $50.6 \mathrm{ab}$ & ${ }^{\mathrm{ns}} 192.9$ & $201.9 \mathrm{a}$ \\
\hline 21 & ${ }^{\mathrm{ns}} 49.5 \mathrm{ab}$ & $49.1 \mathrm{ab}$ & ${ }^{\mathrm{ns}} 194.2$ & $195.8 \mathrm{ab}$ \\
\hline 28 & ${ }^{\mathrm{ns}} 48.2 \mathrm{ab}$ & $49.9 \mathrm{ab}$ & ${ }^{\mathrm{ns}} 194.9$ & $191.3 \mathrm{abc}$ \\
\hline 35 & ${ }^{\mathrm{ns}} 44.2 \mathrm{ab}$ & $52.9 \mathrm{ab}$ & ${ }^{\mathrm{ns}} 194.4$ & $181.7 \mathrm{bc}$ \\
\hline 156 & $* 58.1 \mathrm{a}$ & $33.6 \mathrm{~b}$ & ns 191.4 & $175.8 \mathrm{c}$ \\
\hline $\mathrm{CV}(\%)$ & 15.0 & 15.0 & 3.6 & 3.6 \\
\hline
\end{tabular}

1 ' Days after emergence; ${ }^{2 /}$ Means followed by different letters, in the column, differ by Tukey's test ( $\left.\leq \leq 0.05\right)$ or ${ }^{\mathrm{ns}}$ not significant; ${ }^{3 /}$ Means preceded by $*$ or ${ }^{n s}$, compared to each variable in the lines, differ or not, respectively, by a t-test ( $\left.\mathrm{p} \leq 0.05\right)$.

Table 4 - Effects of control and coexistence periods of crabgrass (Digitaria ciliaris) with soybean in variables biological productivity and harvest index

\begin{tabular}{|c|c|c|c|c|}
\hline \multirow{2}{*}{$\begin{array}{l}\text { Periods } \\
\left(\mathrm{DAE}^{1 /}\right)\end{array}$} & \multicolumn{2}{|c|}{ Biological productivity $\left(\mathrm{kg} \mathrm{ha}^{-1}\right)$} & \multicolumn{2}{|c|}{ Harvest index $(\%)$} \\
\hline & Control & Coexistence & Control & Coexistence \\
\hline 0 & $\underline{3}^{3 / \mathrm{ns}} 4516^{\mathrm{ns} \underline{2} /}$ & $6003 \mathrm{a}$ & ${ }^{\mathrm{ns}} 0.38^{\mathrm{ns}}$ & $0.44 \mathrm{a}$ \\
\hline 7 & ${ }^{\mathrm{ns}} 4830$ & $5381 \mathrm{ab}$ & ${ }^{\mathrm{ns}} 0.39$ & $0.44 \mathrm{a}$ \\
\hline 14 & ${ }^{\mathrm{n}}{ }_{5260}$ & $4925 \mathrm{ab}$ & ${ }^{\mathrm{ns}} 0.41$ & $0.43 \mathrm{a}$ \\
\hline 21 & ${ }^{\mathrm{ns}} 5372$ & $5038 \mathrm{ab}$ & ${ }^{\mathrm{ns}} 0.40$ & $0.43 \mathrm{a}$ \\
\hline 28 & ${ }^{\mathrm{ns}} 5608$ & $5547 \mathrm{ab}$ & ${ }^{\mathrm{ns}} 0.41$ & $0.43 \mathrm{a}$ \\
\hline 35 & ${ }^{\mathrm{ns}} 4838$ & $5220 \mathrm{ab}$ & ${ }^{\mathrm{ns}} 0.41$ & $0.44 \mathrm{a}$ \\
\hline 156 & $* 6065$ & $2779 \mathrm{~b}$ & $* 0.44$ & $0.36 \mathrm{~b}$ \\
\hline $\mathrm{CV}(\%)$ & 19.4 & 19.4 & 6.6 & 6.6 \\
\hline
\end{tabular}

${ }^{1 /}$ Days after emergence; ${ }^{2 /}$ Means followed by different letters, in the column, differ by Tukey's test ( $\left.\leq \leq 0.05\right)$ or ${ }^{\text {ns }}$ not significant; ${ }^{3}$ Means preceded by $*$ or ${ }^{\text {ns }}$, compared to each variable in the lines, differ or not, respectively, by a t-test $(\mathrm{p} \leq 0.05)$.

Another study with soybean showed reductions on the number of pods per plant, of pod grains and pod per area, due to the interference of weeds (Silva et al., 2008). TGM differed only between the periods of coexistence and it was not significantly altered until 28 DAE. However, the coexistence of soybean with crabgrass on period 35 DAE resulted in soybean grains with lower TGM, at least until 21 DAE. However, it did not differ in the TGM observed during the period of coexistence with crabgrass up until the end of the crop's cycle (156 DAE). According to Silva et al. (2008), the soybean TGM reduction depends on the intensity of competition for environmental resources, being altered from the first days of coexistence when there's a high infestation on the area.
ABP and HI differed between control and coexistence only on $156 \mathrm{DAE}$, being the lower values resulted from the coexistence of soybean with crabgrass until 156 DAE (Table 4). On periods of control, ABP was not modified. On periods of coexistence, ABP did not alter until 35 DAE. However, when crops coexisted with crabgrass until 156 DAE, there was a lowered variable in relation to no coexistence. This ABP reduction is due to the effects of inter specific competition, promoting less accumulation of dry mass of soybean. Similar results were observed in other studies with soybean crops (Fleck et al., 2002), and wheat (Agostinetto et al., 2008). For HI, there was a verified reduction of the variables when soybean coexisted with crabgrass during the 
entire development cycle in relation to the initial periods.

Treatments wherein the soybean is kept in the absence of crabgrass, during the initial growing periods, allowed estimate the time which this weed can emerge and infest soybean, without causing any harm to the crop yield (Figure 3). Considering the 3.17\% value of the estimated maximum yield by equation $\left(2.175 \mathrm{~kg} \mathrm{ha}^{-1}\right)$, as being the cost of chemical control, it was determined that PBI for crabgrass occurred from emergence until 23 DAE. Meanwhile, the total period of interference prevention (TPIP), calculated by model, was of 50 DAE. Therefore, the critical period of interference prevention (CPIP), during which control practices should be effectively done, comprehended the period of 23 to $50 \mathrm{DAE}$ of soybean crop.

Periods of competition determined with different species of weeds on soybean crop showed results close to the present study, with a PBI of 20 (Fleck et al., 2002) and CPIP from 7 to 53 and 18 to 47 DAE (Melo et al., 2001), 33 to 66 and 34 to 76 DAE (Nepomuceno et al., 2007). These variations occur due to the infesting species and population of weeds present on the area, regardless of the cultural handling techniques.

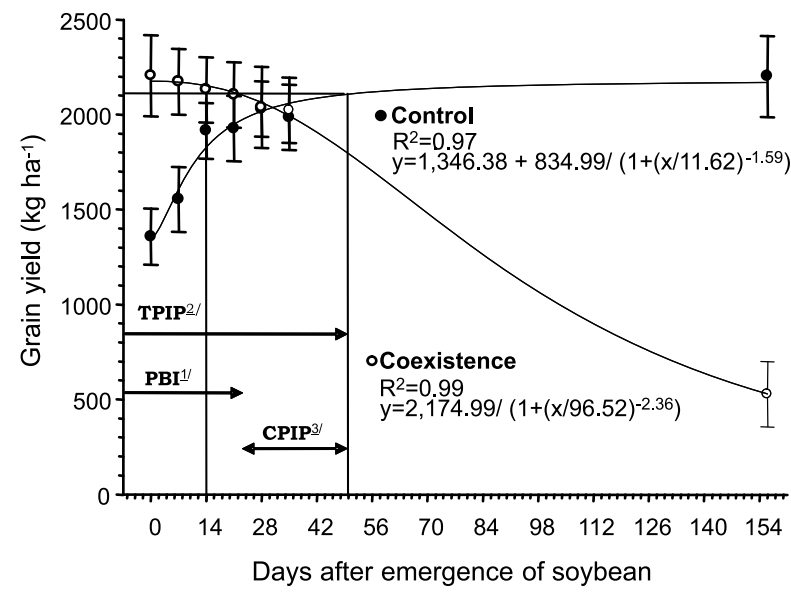

1/2 Períod before interference; ${ }^{2 /}$ Total period of interference prevention; ${ }^{3}$ Critical period of interference prevention.

Figure 3 - Definition of control and coexistence periods of crabgrass (Digitaria ciliaris) in soybeans, based on the grain yield.
CPIP's determination in soybean crop and in other crops is fundamental for the use of techniques that controlled weeds in the right period of time so as to prevent yield losses and the unnecessary use of herbicides.

The results allow for the conclusion that flooded rice crop can coexist with an infestation of crabgrass until 18 days after emergence, without occurring reductions in the crop's yield and its components. Soybean must be free from crabgrass's presence between 23 and 50 days after emergence. Grain yield and its components, for flooded rice and soybean, are altered by coexisting with crabgrass.

\section{ACKNOWLEDGEMENTS}

To CNPq and CAPES for scholarships.

\section{LITERATURE CITED}

AGOSTINETTO, D. et al. Interferência de capim-arroz (Echinochloa spp.) na cultura do arroz irrigado (Oryza sativa) em função da época de irrigação. Planta Daninha, v. 25, n. 4, p. 689-696, 2007.

AGOSTINETTO, D. et al. Período crítico de competição de plantas daninhas com a cultura do trigo. Planta Daninha, v. 26, n. 2, p. 271-278, 2008.

AGROLINK - Histórico de cotações. Cotações. Disponível em: <http://www.agrolink.com.br/cotacoes $>$. Acesso em: 15 jul. 2011.

ANDRES, A. et al. Competição de capim-arroz (Echinochloa crusgalli) em arroz irrigado: épocas de controle e prejuízos à cultivar BRS Querência. Pelotas: Embrapa Clima Temperado, 2008. 14 p.

BALBINOT JR., A. A. et al. Competitividade de cultivares de arroz irrigado com cultivar simuladora de arrozvermelho. Pesq. Agropec. Bras., v. 38, n. 1, p. 53-59, 2003.

FLECK, N. G. et al. Período crítico para controle de Brachiaria plantaginea em função de épocas de semeadura da soja após dessecação da cobertura vegetal. Planta Daninha, v. 20, n. 1, p. 53-62, 2002.

MELO, H. B. et al. Interferência das plantas daninhas na cultura da soja cultivada em dois espaçamentos entre linhas. Planta Daninha, v. 19, n. 2, p. 187-191, 2001. 
NEPOMUCENO, M. et al. Períodos de interferência das plantas daninhas na cultura da soja nos sistemas de semeadura direta e convencional. Planta Daninha, v. 25, n. 1, p. 43-50, 2007.

RADOSEVICH, S.; HOLT, J.; GHERSA, C. Ecology of weeds and invasive plants: relationship to agriculture and natural resource management. 3.ed. New York: Wiley, 2007. 589 p.
SILVA, A. F. et al. Densidades de plantas daninhas e épocas de controle sobre os componentes de produção da soja.

Planta Daninha, v. 26, n. 1, p. 65-71, 2008.

STECKEL, L. E.; SPRAGUE, C. L. Late-season common water hemp (Amaranthus rudis) interference in narrow- and wide-row soybean. Weed Technol., v. 18, n. 4, p. 947-952, 2004. 